\title{
The Insect Type 1 Tyramine Receptors: From Structure to Behavior
}

\author{
Luca Finetti $^{1}(\mathbb{D})$, Thomas Roeder ${ }^{2,3}$, Girolamo Calò ${ }^{4}$ and Giovanni Bernacchia ${ }^{1, *(D)}$ \\ 1 Department of Life Science and Biotechnologies, University of Ferrara, via Borsari 46, 44121 Ferrara, Italy; \\ fntlcu1@unife.it \\ 2 Laboratory of Molecular Physiology, Department of Zoology, Kiel University, Christian-Albrechts-Platz 4, \\ 24118 Kiel, Germany; troeder@zoologie.uni-kiel.de \\ 3 German Center for Lung Research (DZL), Airway Research Center North (ARCN), 24118 Kiel, Germany \\ 4 Department of Pharmaceutical and Pharmacological Sciences, University of Padova, Via VIII Febbraio, 2, \\ 35122 Padova, Italy; girolamo.calo@unipd.it \\ * Correspondence: bhg@unife.it; Tel.: +39-053-245-5784
}

Citation: Finetti, L.; Roeder, T.; Calò, G.; Bernacchia, G. The Insect Type 1 Tyramine Receptors: From Structure to Behavior. Insects 2021, 12, 315. https://doi.org/10.3390/ insects12040315

Academic Editor: Ken Sasak

Received: 2 March 2021

Accepted: 29 March 2021

Published: 1 April 2021

Publisher's Note: MDPI stays neutral with regard to jurisdictional claims in published maps and institutional affiliations.

Copyright: (c) 2021 by the authors. Licensee MDPI, Basel, Switzerland. This article is an open access article distributed under the terms and conditions of the Creative Commons Attribution (CC BY) license (https:// creativecommons.org/licenses/by/ $4.0 /)$.
Simple Summary: This review aims to describe the type 1 tyramine receptors (TAR1s) in insects with a multidisciplinary approach and might be an important tool for a wide scientific audience, including biochemists, molecular physiologists, ethologists, and neurobiologists with a biological entomology background. In fact, in the last years, TAR1 has received much attention due to its broad general interest. The review is composed of a general introduction about the tyraminergic and octopaminergic systems and the corresponding tyramine (TA) and octopamine (OA) receptors, including the recent classification as well as their brief structural and functional information. The four chapters then describe TAR1s: (1) Molecular and structural characterization, with the purpose to provide a clear biochemical overview of the receptor that ensures a well-defined TAR1 identity; (2) pharmacology, in which a clear TAR1-mediated intracellular signaling pathway is detailed; (3) physiology and behavior, focusing on the TAR1-controlled traits in insects; (4) insecticide target, in which the knowledge on TAR1 roles in insects is associated with the growing evidence about the pest management strategies based on this receptor. The conclusions summarize TAR1 features as well as future directions on which the receptor research should move.

Abstract: Tyramine is a neuroactive compound that acts as neurotransmitter, neuromodulator, and neurohormone in insects. Three G protein-coupled receptors, TAR1-3, are responsible for mediating the intracellular pathway in the complex tyraminergic network. TAR1, the prominent player in this system, was initially classified as an octopamine receptor which can also be activated by tyramine, while it later appeared to be a true tyramine receptor. Even though TAR1 is currently considered as a well-defined tyramine receptor and several insect TAR1s have been characterized, a defined nomenclature is still inconsistent. In the last years, our knowledge on the structural, biochemical, and functional properties of TAR1 has substantially increased. This review summarizes the available information on TAR1 from different insect species in terms of basic structure, its regulation and signal transduction mechanisms, and its distribution and functions in the brain and the periphery. A special focus is given to the TAR1-mediated intracellular signaling pathways as well as to their physiological role in regulating behavioral traits. Therefore, this work aims to correlate, for the first time, the physiological relevance of TAR1 functions with the tyraminergic system in insects. In addition, pharmacological studies have shed light on compounds with insecticidal properties having TAR1 as a target and on the emerging trend in the development of novel strategies for pest control.

Keywords: tyramine; octopamine; G protein-coupled receptor; pharmacology; physiology; monoterpenes 


\section{Introduction: The Tyraminergic and Octopaminergic Systems in Insects}

In insects, the main biogenic amines are dopamine (DA), serotonin (5-HT), tyramine (TA), and octopamine (OA). Together, they control and modulate a broad range of biological functions essential for the life of the insects. Whereas DA and 5-HT functions and pathways are highly conserved in both vertebrates and invertebrates, TA and OA can be considered the invertebrate counterparts of the catecholamines epinephrine and norepinephrine of vertebrates [1]. TA, OA, and the catecholamines epinephrine and norepinephrine have many features in common: They are synthesized from the same precursor amino acid (tyrosine), share both structural and functional characteristics such as interaction with $G$ proteincoupled receptors (GPCRs), and regulate similar behavioral and physiological traits [2]. To generate OA and TA, tyrosine is decarboxylated by the tyrosine decarboxylase (Tdc), which gives rise to TA. This is then hydroxylated to OA by the tyramine $\beta$-hydroxylase (T $\beta$ h) [3]. The insect nervous tissues contain high levels of both OA and TA, supporting the view that they act as neurotransmitters [1]. Moreover, they act also as neuromodulators and neurohormones in a wide variety of physiological processes, also operating in a paracrine, endocrine, and autocrine fashion in peripheral organs [4,5]. Originally, TA was considered only as the intermediate product necessary for the synthesis of OA [6]. Nowadays, it is known that TA and OA perform important functions independently of each other [7]. In many cases, TA and OA operate as antagonist modulators in a coordinated way [3] to control important functions in insects, including olfaction [8], locomotion [9], fertilization and reproduction [10], and metabolism [11]. OA and TA exert their physiological actions by interacting with and activating different receptors, the tyramine (TAR) and the octopamine (OAR) receptors [3]. The study of TA and/or OA receptor-deficient animals has revealed that the corresponding receptors play important roles in modulating the biology, physiology, and behavior of invertebrates. In fact, changing the normal function of these receptor classes by blocking or overstimulating them can lead to the death of an insect or interfere with physical fitness and reproductive capacity [12]. These receptors are classified into five main groups based on their primary structure: $\alpha 1$-adrenergic-like receptors (Oct $\alpha 1 R$, also known as OAMB or OA1), $\alpha 2$-adrenergic-like receptors (Oct $\alpha 2 R$, also known as OA3), $\beta$-adrenergic-like receptors (Oct $\beta R$, also known as OA2), tyramine type 1 receptors (TA/OA, Tyr1-R or TAR1), and tyramine type 2 and 3 receptors (Tyr2-R or TAR2 and Tyr3-R or TAR3) [13,14]. To date, the gene coding for TAR3 has only been identified in Drosophila [15]. Oct $\alpha$-Rs have structural and functional similarities to mammalian $\alpha$-adrenergic receptors and are classified in Oct $\alpha 1-R$ and Oct $\alpha 2-R$. Oct $\alpha 1-R$, characterized for the first time in Drosophila melanogaster [16], is expressed mostly in the insect brain [17] and has been identified in other insects, such as Apis mellifera [18], Periplaneta americana [19], and Bombyx mori [20]. All $\alpha$-adrenergic-like OA receptors play key roles in appetitive olfactory learning [21], reproduction [22], circadian clock, and sleep modulation [23]. The other OA receptors (Oct $\beta-R)$ share similarities with mammalian $\beta$-adrenergic receptors and are able to directly control different functions, including ovulation [24], locomotor activity [25], and feeding [26]. The TAR1 receptor group, showing a limited selectivity for TA and the ability to couple with $G_{i}$ and $G_{q}$ proteins, is described in the next chapters. On the other hand, TAR2 is thought to be a receptor highly specific for TA, and its activation elicits a selective stimulation of $\mathrm{Ca}^{2+}$ release [27]. TAR2 seems to be involved in the regulation of renal function due to its high expression in Malpighian tubules, as well as a direct controller of courtship behaviors in fruit flies [28-31]. In contrast, TAR3 is activated by TA and, to a lesser extent, by OA, and decreases intracellular cAMP but also increases $\mathrm{Ca}^{2+}$ levels $[13,15]$. The five OARs and three TARs have been shown to be differentially expressed in Drosophila [32], therewith confirming their multiple and often unique roles in controlling physiology and behavior in insects. Since OARs and TARs play pivotal roles in insect physiology, they are also possible targets for insecticides used in pest control [33]. 


\section{TAR1: Molecular and Structural Characterization}

TAR1s, like all GPCRs, consist of a single polypeptide chain containing seven hydrophobic transmembrane domains, connected by six hydrophilic loops, along with an extracellular $\mathrm{N}$-terminal and an intracellular C-terminal region [34]. To date, TAR1s have been characterized in 16 insect species (Table 1).

Table 1. Molecular features of TAR1s cloned from insects.

\begin{tabular}{|c|c|c|c|c|c|c|c|}
\hline Species & $\begin{array}{l}\text { Accession } \\
\text { number }\end{array}$ & $\begin{array}{l}\text { Amino Acid } \\
\text { Sequence } \\
\text { Lenght }\end{array}$ & $\begin{array}{c}\text { Residues } \\
\text { Interacting with } \\
\text { TA }\end{array}$ & $\begin{array}{l}\text { N-Linked } \\
\text { Glycosylation }\end{array}$ & P Sites & $\begin{array}{l}\text { IL3 } \\
\text { Lenght }\end{array}$ & Reference \\
\hline D. melanogaster & AAA28731 & 601 & / & $\mathrm{N}^{11} ; \mathrm{N}^{57}$ & $\begin{array}{c}\mathrm{T}^{136} ; \mathrm{T}^{296} ; \mathrm{S}^{375} ; \mathrm{S}^{397} ; \mathrm{S}^{406} \\
\mathrm{~S}^{482} ; \mathrm{S}^{507}\end{array}$ & 237 & [35] \\
\hline D. suzukii & MK405664 & 600 & $\begin{array}{l}\mathrm{D}^{187} ; \mathrm{S}^{271} \\
\mathrm{~S}^{272} ; \mathrm{S}^{275}\end{array}$ & $\mathrm{~N}^{11} ; \mathrm{N}^{55}$ & $S^{420} ; S^{506} ; S^{519}$ & 238 & [36] \\
\hline P. regina & AB621975 & 607 & 1 & I & I & 246 & [37] \\
\hline L. migratoria & X69520 & 484 & $D^{130}$ & $\mathrm{~N}^{13} ; \mathrm{N}^{198}$ & $\begin{array}{c}\mathrm{T}^{78} ; \mathrm{T}^{164} ; \mathrm{T}^{238} ; \mathrm{T}^{300} ; \mathrm{S}^{304} \\
\mathrm{~S}^{365} ; \mathrm{S}^{372}\end{array}$ & 174 & [38] \\
\hline A. mellifera & AJ245824 & 399 & $\begin{array}{l}\mathrm{D}^{116} ; \mathrm{S}^{200}: \\
\mathrm{S}^{201} ; \mathrm{S}^{204}\end{array}$ & $\mathrm{~N}^{2}$ & $\begin{array}{c}\mathrm{T}^{63} ; \mathrm{T}^{149} ; \mathrm{T}^{223} ; \mathrm{S}^{241} ; \mathrm{T}^{265} ; \mathrm{S}^{291} \\
\mathrm{~S}^{292} ; \mathrm{T}^{296}\end{array}$ & 110 & [39] \\
\hline B. mori & X95607 & 479 & $\mathrm{D}^{134} ; \mathrm{S}^{218} ; \mathrm{S}^{222}$ & $\mathrm{~N}^{11} ; \mathrm{N}^{16}$ & $\mathrm{~T}^{81} ; \mathrm{T}^{241} ; \mathrm{T}^{258} ; \mathrm{T}^{302}$ & 162 & {$[40,41]$} \\
\hline H. virescens & CAA64864 & 477 & $\mathrm{D}^{132}$ & $\mathrm{~N}^{11} ; \mathrm{N}^{16}$ & $\mathrm{~T}^{78} ; \mathrm{T}^{238} ; \mathrm{T}^{298} ; \mathrm{T}^{302}$ & 165 & {$[40]$} \\
\hline P. americana & AM990461 & 441 & $\begin{array}{l}\mathrm{D}^{115} ; \mathrm{S}^{99} ; \\
\mathrm{W}^{381} ; \mathrm{N}^{418}\end{array}$ & $\mathrm{~N}^{12}, \mathrm{~N}^{17}$ & $\begin{array}{c}\mathrm{T}^{61} ; \mathrm{T}^{222} ; \mathrm{S}^{275} ; \mathrm{S}^{285} ; \mathrm{S}^{326} ; \\
\mathrm{T}^{334} ; \mathrm{S}^{341}\end{array}$ & 144 & [42] \\
\hline P. americana & LT900530 & 481 & $\mathrm{D}^{120} ; \mathrm{S}^{204} ; \mathrm{S}^{208}$ & $\mathrm{~N}^{7} ; \mathrm{N}^{17}$ & $\begin{array}{l}\mathrm{S}^{64} ; \mathrm{T}^{153} ; \mathrm{T}^{227} ; \mathrm{S}^{238} ; \mathrm{S}^{252} ; \mathrm{T}^{279} \\
\mathrm{~T}^{280} ; \mathrm{S}^{282} ; \mathrm{T}^{289} ; \mathrm{S}^{300} ; \mathrm{T}^{350} ; \mathrm{T}^{351} \\
\mathrm{~S}^{354} ; \mathrm{S}^{379} ; \mathrm{S}^{398} ; \mathrm{P}^{408}\end{array}$ & 188 & [43] \\
\hline C. suppressalis & AFG26689.1 & 478 & $\mathrm{D}^{135} ; \mathrm{S}^{219} ; \mathrm{S}^{223}$ & $\mathrm{~N}^{11} ; \mathrm{N}^{16} ; \mathrm{N}^{347}$ & $\begin{array}{c}\mathrm{T}^{205} ; \mathrm{T}^{267} ; \mathrm{S}^{274} ; \mathrm{T}^{304} ; \mathrm{S}^{315} \\
\mathrm{~T}^{371} ; \mathrm{S}^{396}\end{array}$ & 170 & [44] \\
\hline R. prolixus & MF377527 & 447 & / & $\mathrm{N}^{14} ; \mathrm{N}^{17}$ & $\begin{array}{l}\mathrm{T}^{75} ; \mathrm{T}^{235} ; \mathrm{S}^{246} ; \mathrm{S}^{265} ; \mathrm{S}^{271} ; \mathrm{S}^{274} \\
\mathrm{~S}^{295} ; \mathrm{S}^{298} ; \mathrm{S}^{311} ; \mathrm{S}^{319} ; \mathrm{S}^{320} ; \mathrm{S}^{322} \\
\mathrm{~S}^{338} ; \mathrm{T}^{354} ; \mathrm{S}^{371} ; \mathrm{S}^{373}\end{array}$ & 161 & [45] \\
\hline P. xylostella & MK166023 & 467 & $\mathrm{D}^{127} ; \mathrm{S}^{211} ; \mathrm{S}^{215}$ & $\mathrm{~N}^{5} ; \mathrm{N}^{10}$ & $\begin{array}{c}\mathrm{S}^{252} ; \mathrm{S}^{268} ; \mathrm{S}^{271} ; \mathrm{T}^{296} ; \mathrm{S}^{307} ; \mathrm{S}^{322} \\
\mathrm{~S}^{349} ; \mathrm{S}^{352} ; \mathrm{S}^{385}\end{array}$ & 168 & [46] \\
\hline H. halys & MT513133 & 449 & $\begin{array}{l}\mathrm{D}^{128} ; \mathrm{S}^{212} \\
\mathrm{~S}^{213} ; \mathrm{S}^{216}\end{array}$ & $\mathrm{~N}^{11} ; \mathrm{N}^{14} ; \mathrm{N}^{22}$ & $\begin{array}{c}\mathrm{S}^{24} ; \mathrm{T}^{30} ; \mathrm{T}^{161} ; \mathrm{T}^{235} ; \mathrm{S}^{246} ; \mathrm{S}^{260} \\
\mathrm{~S}^{294} ; \mathrm{S}^{319} ; \mathrm{S}^{321} ; \mathrm{S}^{364}\end{array}$ & 147 & [47] \\
\hline M. brassicae & AF343878 & 477 & $\mathrm{D}^{136}$ & 1 & I & 174 & [48] \\
\hline P.xuthus & AB182633 & 475 & $\mathrm{D}^{131}$ & I & I & 171 & [49] \\
\hline A. ipsilon & FJ640850 & 477 & $\begin{array}{l}\mathrm{D}^{149} ; \mathrm{S}^{216} \\
\mathrm{~S}^{217} ; \mathrm{S}^{220}\end{array}$ & $\mathrm{~N}^{11} ; \mathrm{N}^{16} ; \mathrm{N}^{345}$ & $\begin{array}{c}\mathrm{T}^{79} ; \mathrm{T}^{165} ; \mathrm{T}^{239} ; \mathrm{T}^{265} ; \mathrm{S}^{314} ; \\
\mathrm{S}^{333} ; \mathrm{S}^{383}\end{array}$ & 177 & [50] \\
\hline S. oryzae & A0A0S1VX60 & 455 & $\begin{array}{l}\mathrm{V}^{83} ; \mathrm{D}^{114} ; \mathrm{C}^{118} \\
\mathrm{~W}^{394} ; \mathrm{N}^{427} ; \mathrm{S}^{428}\end{array}$ & / & / & 158 & [51] \\
\hline
\end{tabular}

Recently, it has been reported that P. americana expresses a second type 1 tyramine receptor, named PeaTAR1B (accession number: LT900530), in addition to the PeaTYR1 or PeaTAR1A (accession number: AM990461) [42,43]. PeaTAR1B appears structurally related to PeaTAR1A, sharing several biochemical features such as N-glycosylation and P sites, as well as amino acids involved in the binding with TA (Table 1). The first TAR1 was described in D. melanogaster and called Tyr-dro [35]. The amino acid sequence, composed by 601 residues, is significantly longer compared to other TAR1s (Table 1). In fact, in $D$. melanogaster TAR1, a putative eighth transmembrane domain was found close to the $\mathrm{N}$-terminal region [35]. The same domain was reported also in Drosophila suzukii and Phormia regina TAR1 [36,37] but it seems to be exclusive to the order Diptera. As suggested by Baxter and Barker [52], this eighth domain might be a cleavable signal sequence or leader peptide, a sequence that plays a key role during the first steps of the GPCRs intracellular transport [53]. However, the exact function of this domain remains to be clarified. Several sequence motifs essential for correct receptor folding, ligand binding, 
and signal transduction are well conserved within the TAR1 family. Between the fifth and sixth transmembrane domain, there is the long intracellular loop 3 (IL3) composed of about 150 amino acids [34]. Interestingly, in Diptera, the TAR1 IL3 is longer than in other insects. In particular, IL3 is 237, 238, and 246 residues long in D. melanogaster, D. suzukii, and $P$. regina, respectively [35-37]. In the $\beta$-adrenergic receptors, the IL3 is involved in intracellular signaling activation [54]. Given the evolutionary proximity between TAR1 and adrenergic receptors, it cannot be excluded that the IL3 region might play the same role. Braza and colleagues have observed that, in the Sitophilus oryzae TAR1, the IL3 region is a very flexible element and is stabilized by TA binding, a key event for signaling with the G-protein [51]. However, A. mellifera TAR1 has a relatively short IL3, composed of 110 amino acids. Blenau and colleagues linked this unusual aspect to the fact that this receptor couples only with $\mathrm{G}_{\mathrm{i}}$ and not also with $\mathrm{G}_{\mathrm{q}}$ [39]. The GPCRs are subjected to a variety of post-translational modifications among which glycosylation, phosphorylation, and palmitoylation are the most prominent [55]. In all the TAR1s characterized, two putative N-glycosylation sites within the N-terminal region have been identified (Table 1). The number of phosphorylation site ranges from 3 (D. suzukii TAR1) to 19 (Rhodnius prolixus TAR1) [36,45]. These sites are generally phosphorylated by protein kinase $C(\mathrm{PKC})$ or protein kinase $\mathrm{A}(\mathrm{PKA})$, modulating the sensitivity of the receptor to coupling with $G$ proteins [56]. Palmitoylation is the addition of a palmitic acid residue (a 16C saturated fatty acid) and occurs on one or more cysteines on the intracellular side of GPCRs, typically in the C-terminal region [57]. In TAR1s, putative palmitoylation sites have not been identified. This could be explained by the extremely short C-terminal region (15-20 aa) which does not contain cysteine residues. This aspect is shared with $\alpha 2$-adrenergic receptors [58]. In fact, palmitoylation is an event that generally influences the choice of signaling through particular $\mathrm{G}$ proteins as well as receptor phosphorylation and internalization [57]. A conserved domain, coding for the amino acids DRY, immediately downstream of the third transmembrane domain, was identified in all TAR1s examined. This motif appears important for the stabilization of GPCRs between inactive and activate conformations and is typical of catecholaminergic receptors. The DRY domain and a glutamate residue in the sixth transmembrane domain create an ionic lock that stabilizes the inactive conformation of the receptor [59]. Through site-directed mutagenesis, Ohta and colleagues were the first to identify the amino acid residues involved in TA binding of B. mori TAR1 [60]. In particular, in the mutant D134A the TA-mediated cAMP reduction observed in wild-type B. mori TAR1 was completely abolished. Furthermore, the double mutant S218A and S222A was also not able to attenuate cAMP levels after stimulation with TA. The authors suggested a binding scheme by which the carboxylic group of D134 residue forms an ion pair with the protonated amine of TA, while the S218 and S222 are involved in H-bond between the hydroxyl groups.

Through molecular docking approaches, Braza and colleagues confirmed that S. oryzae TAR1 binds TA by forming H-bonds with $\mathrm{D}^{114}$ (in the third transmembrane domain) and with $\mathrm{N}^{427}$ (in the sixth transmembrane domain) [51]. Furthermore, this study reveals that other amino acid residues, such as $\mathrm{V}^{83}, \mathrm{C}^{118}, \mathrm{~W}^{394}$ and $\mathrm{S}^{428}$, are involved in TA binding suggesting a more complex binding pocket for TA.

\section{TAR1: Pharmacology}

The characterization of a receptor downstream signaling and cascade requires a precise study of its pharmacological profile. The TAR1 pharmacology is quite intriguing, since it was initially characterized as an OA receptor capable of also interacting with TA. Arakawa was the first to pharmacologically characterize a TAR1 by cloning and expressing the D. melanogaster TAR1 in Chinese Hamster Ovary (CHO)-K1 cells [61]. In this study, several biogenic amines were tested as putative agonists, including 5-HT, adrenaline, and OA, but not TA. The authors concluded that the receptor was an OA receptor given its high affinity to OA. However, in two separate studies, the same receptor was further investigated [35,62]. When expressed in mammalian cells (Cos-7), it showed a TA-mediated inhibition of adenylate cyclase activity, proving its $G_{i}$ coupling activity. In particular, 
TA was able to reduce forskolin-stimulated cAMP levels in a dose-dependent manner with a pEC 50 of 5.62 (Table 2).

Table 2. Functional and pharmacological properties of TAR1s cloned from insects.

\begin{tabular}{|c|c|c|c|c|c|c|}
\hline Species & G-Protein & $\mathrm{pEC}_{50} \mathrm{TA}$ & $\mathrm{pEC}_{50} \mathrm{OA}$ & Cell Line Used & Antagonist & Reference \\
\hline \multirow{2}{*}{ D. melanogaster } & $\mathrm{Gi}$ & 5.62 & 4.52 & Cos-7 & Yohimbine (tested at $1 \mu \mathrm{M}$ ) & [35] \\
\hline & Gi & 5.24 & I & $\mathrm{S} 2$ & I & [63] \\
\hline \multirow{2}{*}{ D. suzukii } & $\mathrm{Gq}$ & 6.35 & \multirow{2}{*}{$\begin{array}{l}\text { Detectable to } \\
10 \mu \mathrm{M}\end{array}$} & \multirow{2}{*}{ HEK 293} & Yohimbine: $\mathrm{pA}_{2} 7.87$ & \multirow{2}{*}[36]{} \\
\hline & $\mathrm{Gq}+\mathrm{Gi}$ & 6.86 & & & Yohimbine: $\mathrm{pA}_{2} 7.24$ & \\
\hline \multirow[t]{2}{*}{ L. migratoria } & $\mathrm{Gq}$ & 7.33 & $\begin{array}{c}\text { Detectable to } \\
10 \mu \mathrm{M}\end{array}$ & \multirow{2}{*}{$\begin{array}{l}\text { Murine } \\
\text { Erythroleukaemia }\end{array}$} & Yohimbine (tested at $2.5 \mu \mathrm{M}$ ) & \multirow[t]{2}{*}[64]{} \\
\hline & Gi & 8.40 & / & & / & \\
\hline \multirow{2}{*}{ A. mellifera } & $\mathrm{Gi}$ & 6.86 & 5.56 & HEK 293 & / & [39] \\
\hline & Gi & 7.07 & / & Sf9 & I & [65] \\
\hline B. mori & Gi & 8.28 & 5.85 & HEK 293 & $\begin{array}{c}\text { Yohimbine }> \\
\text { Chlorpromazine }> \\
\text { Metoclopramide }> \\
\text { Mianserin }(\text { tested at } 10 \mu \mathrm{M})\end{array}$ & [40] \\
\hline P. americana & Gi & 6.46 & / & HEK 293 & $\begin{array}{l}\text { Yohimbine and } \\
\text { Chlorpromazine }>\text { Mianserin } \\
\text { (tested at } 10 \mu \mathrm{M})\end{array}$ & [42] \\
\hline P. americana & Gi & 8.20 & / & HEK 293- CNG & $\begin{array}{l}\text { Yohimbine: } \mathrm{pA}_{2} 6.13 \\
\text { Mianserin: } \mathrm{pA}_{2} 6.06\end{array}$ & [43] \\
\hline C. suppressalis & Gi & 6.43 & 6.01 & HEK 293 & $\begin{array}{c}\text { Yohimbine }> \\
\text { Chlorpromazine }> \\
\text { Cyproheptadine (tested at } \\
10 \mu \mathrm{M})\end{array}$ & [44] \\
\hline R. prolixus & $\mathrm{Gq}$ & 7.29 & 5.16 & HEK 293- CNG & $\begin{array}{c}\text { Yohimbine }> \\
\text { Metoclopramide }> \\
\text { Phentolamine }> \\
\text { Cyproheptamide }>\text { Gramine } \\
>\text { Mianserin }> \\
\text { Chlorpromazine (tested at } \\
10 \mu \mathrm{M})\end{array}$ & [45] \\
\hline P. xylostella & $\mathrm{Gi}$ & 6.35 & 4.86 & HEK 293T & $\begin{array}{c}\text { Yohimbine }>\text { Mianserin }> \\
\text { Phentolamine }> \\
\text { Chlorpromazine (tested at } \\
10 \mu \mathrm{M})\end{array}$ & [46] \\
\hline H. halys & $\mathrm{Gq}$ & 5.99 & 4.41 & HEK 293 & Yohimbine: $\mathrm{pA}_{2} 8.26$ & {$[47]$} \\
\hline
\end{tabular}

Conversely, OA was less potent, with a $\mathrm{pEC}_{50}$ of 4.52 [35]. Furthermore, Robb and colleagues investigated the TA and OA responses of D. melanogaster TAR1 upon cloning into $\mathrm{CHO}$ cells. In particular, this work clearly demonstrated that D. melanogaster TAR1 is more sensitive to TA than $\mathrm{OA}$ and that it activates its signaling cascade not only through $\mathrm{G}_{\mathrm{i}}$-coupling but also via $\mathrm{G}_{\mathrm{q}}$ proteins [62]. TAR1 signaling is, therefore, far more complex than initially thought. Over the years, several TAR1s have been cloned and pharmacologically characterized from other insects, providing a well-grounded description of the receptor pharmacology. TA appears to be significantly more potent than $\mathrm{OA}$ in activating the receptor in terms of both $\mathrm{G}_{\mathrm{i}}$ and $\mathrm{G}_{\mathrm{q}}$-mediated intracellular cascades. In particular, in A. mellifera, D. melanogaster, and D. suzukii, TA appeared to be one order of magnitude more potent than OA, while in R. prolixus, L. migratoria, Plutella xylostella, and Halyomorpha halys, TA was twice as effective as OA (Table 2). These variations in potency might be 
truly species specific or they might be traced back to the different cell lines used: Most of the studies stably expressed TAR1 in the Human Epithelial Kidney (HEK) 293 cell line, while others used insect cell lines (S2 and Sf9), CHO, or Murine Erythroleukaemia cells. Furthermore, another reason for variation in the pharmacological profile might be linked to the different experimental approaches used. In fact, for each TAR1 studied, either the

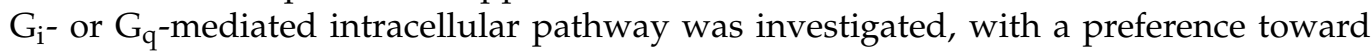
$\mathrm{G}_{\mathrm{i}}$. The reason for investigating the $\mathrm{G}_{\mathrm{i}}$-mediated transduction pathway is perhaps due to the fact that the $\alpha 2$-adrenergic receptors are coupled exclusively to $G_{i}$ [58]. Studies investigating the $\mathrm{G}_{\mathrm{q}}$-mediated intracellular pathway have been performed on TAR1 from D. suzukii, L. migratoria, $R$. prolixus, and H. halys [36,38,45,47]. In the study by Blenau and colleagues, A. mellifera TAR1, expressed in HEK 293 cells, was tested for its ability to activate intracellular signaling via both $\mathrm{G}_{\mathrm{i}}$ and $\mathrm{G}_{\mathrm{q}}$ proteins, and it was shown to promote its downstream cascade exclusively via $G_{i}$ activation. As discussed above, this receptor peculiarity may be due to the shorter IL3, but further investigation might be necessary [39]. D. suzukii TAR1 was the first receptor studied with the dynamic mass redistribution (DMR) assay, an assay able to investigate both the $\mathrm{G}_{\mathrm{i}}$ and $\mathrm{G}_{\mathrm{q}}$ contribution to intracellular signaling simultaneously. In this study, DMR assays revealed that TA is able to evoke a positive concentration dependent signal in HEK 293 cells stably expressing the D. suzukii TAR1 ( $\mathrm{pEC}_{50}$ of 6.87), while OA can elicit an intracellular $\mathrm{Ca}^{2+}$ release only at $10 \mu \mathrm{M}$ [36]. P. americana, as discussed above, is the only insect presenting two distinct TAR1 [42,43]. In fact, the occurrence of two functional TAR1s with different pharmacological properties has not yet been described for any other insect species. In particular, although both PeaTAR1s were activated by TA via $G_{i}$ coupling, PeaTAR1B displayed a different response to antagonist compounds. In fact, several antagonists completely lacked inhibitory potential on the receptor, such as chlorpromazine [43]. In terms of TAR1 antagonist pharmacological profile, yohimbine showed the highest affinity for this receptor class (Table 2). Yohimbine is an $\alpha 2$-adrenergic receptor antagonist and concentrations up to $1 \mu \mathrm{M}$ were able to antagonise TA in TAR1s (Table 2). When the R. prolixus TAR1 was expressed in HEK 293, the rank order of antagonist potency was yohimbine $>$ metoclopramide $>$ phenoxybenzamine $>$ phentolamine $>$ cyproheptamide $>$ gramine $>$ mianserin $>$ chlorpromazine [45]. Similar results, i.e., yohimbine $>$ mianserin $>$ phentolamine $>$ chlorpromazine, were obtained when investigating the P. xylostella TAR1 expressed in HEK 293T cells [47]. When biogenic amines different from TA and OA, such as dopamine, adrenaline, noradrenaline, L-DOPA, and histamine, were tested on TAR1s, no significant agonist effects were observed, suggesting that this receptor class is selectively responsive to TA and OA [40,42,44-47]. The pharmacological profile of TAR1 has been characterized especially for the antagonist, whereas our knowledge of alternative agonists is almost completely lacking. The preferred receptor coupling between $G_{i}$ and $G_{q}$ proteins, whether TA preferably activates the $G_{i}$ - or $G_{q}$-mediated transduction pathway, and how much OA, even though less potent, contributes to this, remain to be elucidated. Nevertheless, it is obvious that TAR1s are promiscuous GPCRs which are able to couple with both $G_{i}$ and $G_{q}$ proteins as summarized in Figure 1 .

Therefore, the TA/OA receptors scheme proposed by Wu and colleagues [13] should be revised, defining TAR1s more sensitive to TA in both $\mathrm{Ca}^{2+}$ and cAMP intracellular variations (Figure 2). 


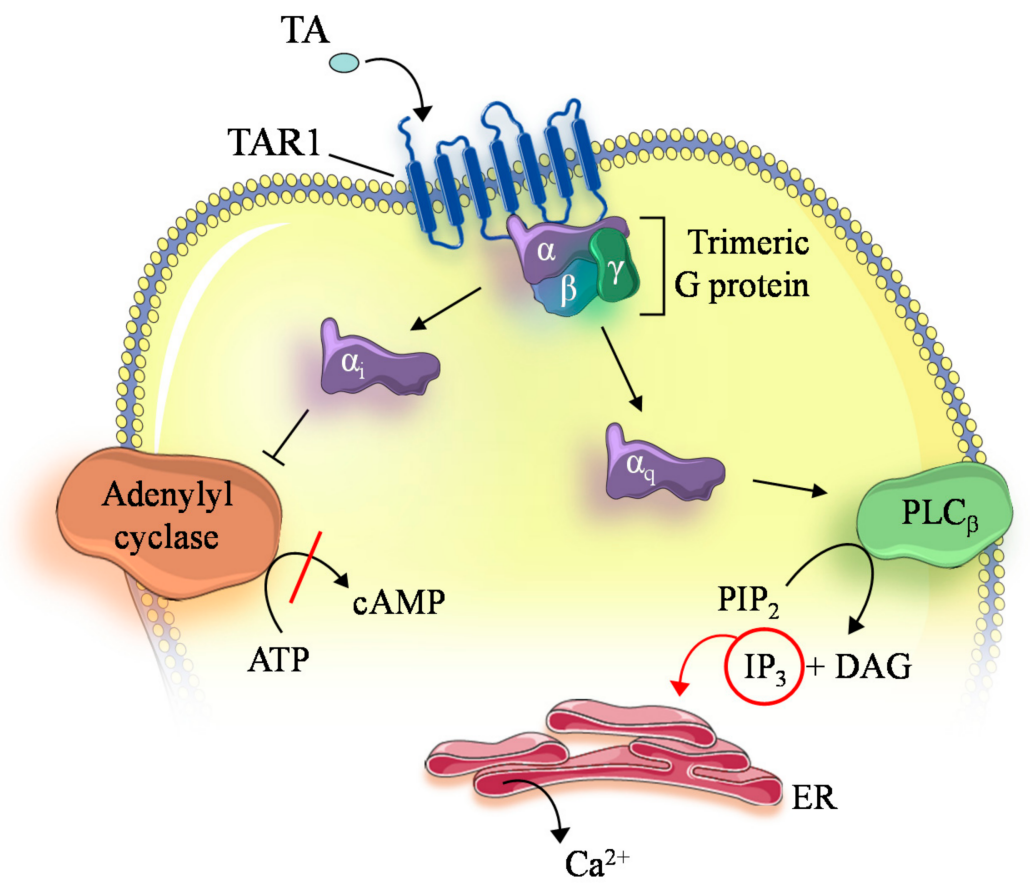

Figure 1. Intracellular signaling pathways trigged by TAR1 activation. ATP (Adenosine triphosphate), cAMP (Cyclic adenosine monophosphate), PLC $\beta$ (phospholipase C $\beta$ ), PIP2 (Phosphatidylinositol 4,5-bisphosphate), IP3 (Inositol trisphosphate), DAG (Diacylglycerol), ER (Endoplasmatic reticulum).

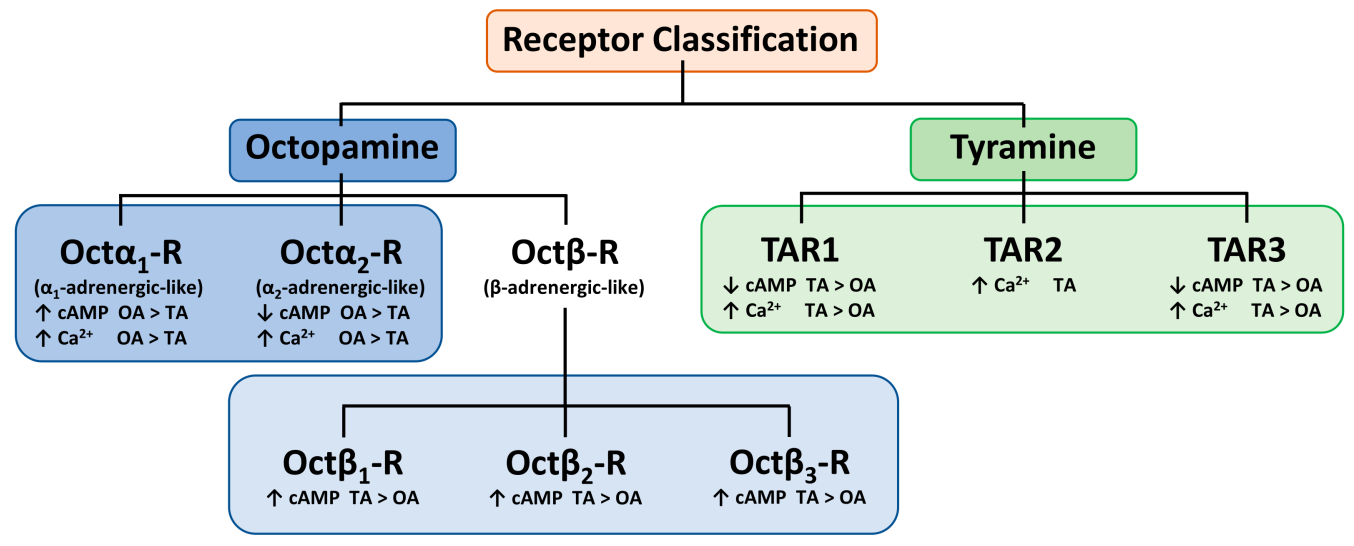

Figure 2. Revised scheme, based on Hana and Lange, describing the tyramine (TA)/octopamine (OA) receptors classification based on their sensitivity to ligands and their downstream effects [45].

\section{TAR1: Physiology and Behavior}

TAR1 transcript localization analysis provides information on the expression profile of the receptor and helps to better understand its physiological and behavioral functions. In $D$. melanogaster, the receptor is mainly expressed in the central nervous system (CNS) [32]. Through Gal4/UAS technology, D. melanogaster TAR1 transcripts were found to be abundant in the pars intercerebralis, in the mushroom bodies, and in the antennal and olfactory lobes [66]. A higher expression of TAR1 in nervous tissues compared to the periphery was also observed in D. suzukii, Chilo suppressalis, R. prolixus, P. xylostella, H. halys, Mamestra brassicae, and Agrotis ipsilon, suggesting a crucial role of the receptor in controlling a broad range of physiological functions and behaviors [36,44-48,50]. Interestingly, TAR1 was also strongly expressed in the antennae of M. brassicae, A. ipsilon, and H. halys, where it could regulate olfactory-mediated behaviors $[8,47,48,50]$. A possible correlation between TAR1 and olfaction was established for the first time in 2000 by Kutsukake and colleagues [67]. 
This study characterized a D. melanogaster TAR1-defective line, called honoka, whose behavioral responses to repellents were reduced in comparison to wild-type flies. Furthermore, using in situ hybridization, Brigaud and colleagues observed that TAR1 was expressed at the base of the olfactory sensilla trichodea, pheromone-sensitive sensilla, rather than in sensilla chaetica, which are mechano-sensitive in A. ipsilon [50]. A similar correlation has been hypothesized in $H$. halys. In the antennae, TAR1 appeared to be highly expressed in flagellomeres, apical structures rich in sensilla trichoidea which are essential for pheromone perception. Furthermore, RNAi-mediated TAR1 silencing resulted in a lower sensitivity to the alarm pheromone $(E)$-2-decenal [47], therefore suggesting a pivotal role of this receptor in olfaction-mediated responses. The role of TAR1 in olfactory perception was further confirmed by imaging analysis performed on A. mellifera. In two studies conducted in 2017 on the honeybee brain, the authors showed that TAR1 is mainly expressed at the presynaptic sites of olfactory receptor neurons (ORNs), innervating the antennal lobes and the mushroom bodies, which are essential structures for the olfactory system $[68,69]$. A similar TAR1 mRNA localization was observed by Mustard and colleagues via in situ hybridization in honeybees [65]. Furthermore, TAR1 showed a higher expression in the antennae of pollen foragers in comparison to nurse ones. In contrast, OAR1 exhibited the opposite expression profile [70]. Therefore, it can be proposed that, in social insects, TAR1 could represent a key element in defining the caste identity and modulating behavioral features such as olfaction [71]. Behavioral alterations caused by TAR1 modulation have been observed in several studies performed with L. migratoria and D. melanogaster. In locusts, the ratio between TAR1 and OAR1 expression levels influenced olfactory preferences during the solitary-gregarious phase transition. In fact, high levels of TAR1 promoted solitary behavior by inducing the perception of gregarious pheromones as repellent, while RNAi-mediated TAR1 downregulation in solitary locusts was able to mediate the transition to the gregarious-like behavior [72]. In a subsequent study, the same authors observed that TAR1 mediates the olfactory responses between the solitary-gregarious phases by modulating the tspo transport protein [73]. It is evident that TAR1 is not only important in olfactory regulation but also in locomotor control. In A. mellifera, movement impairment could be attributed to TAR1 [74], since the topical application of yohimbine on the abdomen caused a massive movement alteration owing to the selective antagonism of the receptor. However, yohimbine also antagonizes TAR2, and further studies are necessary to evaluate which tyramine receptor is essential in this response. A TAR1-mediated role in locomotion has been hypothesized by a few studies reporting a high TAR1 expression in leg muscles of D. melanogaster, P. americana, and A. ipsilon [32,42,50]. Furthermore, T $\beta$ h-deficient flies having no OA but high levels of TA showed a severe locomotion deficit, partially rescued by diet-fed TAR1 antagonist yohimbine [75]. Furthermore, it has been observed that in Drosophila, the TA/OA ratio was modulated by nutritional state, such as satiation and starvation. In particular, satiation inhibits locomotion through the increase of TA levels. Moreover, this mechanism controlling locomotor behavior requires a functional TAR1 in D. melanogaster [76]. However, these observations do not rule out the possibility that TAR1-mediated movement alterations could be controlled by other nervous areas rich in TAR1 transcripts such as the central complex [66]. TAR1 has also been shown to influence the gustatory responses. The $D$. melanogaster TAR1 ${ }^{\text {PL00408 }}$ defective line exhibited higher body fat accumulation, starvation resistance, and food intake in comparison to wildtype flies [66,77], thus suggesting that nutritional constraints work through a functional TA-dependent pathway, even if the precise mechanism by which TAR1 modulates these essential metabolic traits is still unknown. Some indications came from D. melanogaster, where, like many other insects, lipids are mainly stored in the fat body. Their storage and release are mainly controlled by two hormones, the insulin-like peptides (mainly ILP2) and the adipokinetic hormone ( $\mathrm{AKH}$, analogous to the mammalian glucagon) [11]. Under acute stress, mobilization of lipids from the fat body is essential for survival. This mechanism also appears to be controlled by both OA and TA, presumably through the modulation of ILP2 secretion [78,79]. Therefore, the increased triglycerides (TG) level observed in 


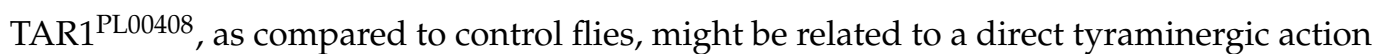
on the ILP2 release. RNAi-mediated D. melanogaster TAR1 silencing, targeted to the fat body, indeed triggered a ILP2 reduction in insulin-producing cells, located in the pars intercerebralis, and an increased TG accumulation [77], confirming a significant role for TAR1 in lipid metabolism. Furthermore, the increased TG levels in TAR1 ${ }^{\text {PL00408 }}$ flies correlates well with other traits observed, such as enhanced food intake, lower movement propensity, and lower metabolic rate [66]. It has recently been proposed that TAR1 could be involved in processes related to sugar sensibility and food intake regulation. honoka flies, a D. melanogaster TAR1-defective line, exhibited a higher starvation resistance but, in contrast to TAR1 $1^{\mathrm{PL} 00408}$ flies, a reduced responsiveness to sugar stimuli compared with control flies [80]. It is worth noting that TAR1 is highly expressed in neurons located in the sub-esophageal ganglia that are presumably associated with the salivary glands and neck muscles control, thus linking TAR1 with feeding. In honeybees, the topical administration of TA induced an increased Gustatory Response Score (GRS) that was sensitive to yohimbine [81]. LeDue and colleagues found that the TAR1 knockdown in D. melanogaster significantly reduced bitter sensitivity in starved flies, suggesting that TAR1 might be directly involved in the gustatory behaviors [82]. Furthermore, foraging honeybees showed a higher GRS as well as higher TAR1 expression level in the fat body in comparison to nurses, suggesting a correlation between the receptor and sugar responsiveness [83]. Last but not least, in both $D$. suzukii and R. prolixus, TAR1 is expressed in the reproductive organs $[36,45]$. In particular, $R$. prolixus ovaries display higher TAR1 transcript levels in comparison to other reproductive tissues such as the lateral oviduct and common oviduct, suggesting its importance in modulating reproductive processes [45]. However, the D. suzukii male abdomens showed a significant difference in the TAR1 expression levels as compared to females, suggesting a possible role of TA in male reproductive system [36]. Recently, TAR1 gene has been successfully downregulated through RNAi approaches in A. mellifera and $H$. halys to investigate the receptor physiological functions $[47,84,85]$. Thus, biotechnological techniques such as RNAi and CRISPR-Cas9, targeting TAR1, might be useful to better dissect out the TAR1 roles in controlling specific behavior in insects.

\section{TAR1: Insecticides Target}

In addition to their role in the physiology and behavioral control of insects, TAR1s have proven to be interesting targets for insecticides. Amitraz is an acaricide and non-systemic insecticide that targets OA receptors [86]. However, recent studies have demonstrated that amitraz can also exert its toxic effect through TAR1 $[44,87]$. When the $C$. suppressalis TAR1 was expressed in HEK 293 cells, $10 \mu \mathrm{M}$ of amitraz was able to inhibit forskolin-stimulated intracellular cAMP, mimicking TA effects [44]. Amitraz was initially thought to work only on OA receptors. However, TAR1s have been wrongly classified as OA receptors $[37,88]$. Through phylogenetic analyses, Baron and colleagues classified the receptor as Oct / Tyr. In Farooqui's review, TAR1 was described as a TA receptor [89,90]. On the other hand, ambiguities and annotation errors still persist in public databases. Further evidence supporting the hypothesis that amitraz could interact with TAR1 was provided by Gross and colleagues on Rhipicephalus microplus TAR1. When expressed in the CHO cell line, TAR1 was allosterically positively modulated by BTS-27271, an amitraz metabolite [91]. Even if it remains to be elucidated whether the biological effects of the insecticide are really due to the activation of TAR1, it has been shown that two amino acid substitutions in the R. microplus TAR1 (T8P and L22S) could be responsible for a lower susceptibility, or even resistance, to the amitraz insecticide action [88], supporting the hypothesis that the amitrazmediated toxicity is mediated by TAR1. The tyraminergic and octopaminergic systems are interesting targets for natural insecticides such as monoterpenes [92]. These molecules are the main components of plant essential oils and have long been used as phagodeterrents and biopesticides in the pest control [93]. In the last few years, several studies have shown that the monoterpenes can directly activate TAR1. Enan [63] was the first to describe an agonist effect of several monoterpenes (thymol, carvacrol, $\alpha$-terpineol, eugenol) on the $D$. 
melanogaster TAR1. However, the same monoterpenes exhibited a different pharmacological effect on D. suzukii and R. microplus TAR1 receptors. In fact, they appeared able to increase the TA potency acting as positive allosteric modulators and not as agonists $[36,94]$. This allosteric modulation of TAR1 was shown to interfere with the receptor expression and subsequently with the insect physiology and behavior [61]. Recent data have revealed that in silico prediction of the structural interaction between monoterpenes and S. oryzae TAR1 might provide new insights and possibly new molecules for TAR1-related pest control [95].

\section{Conclusions and Future Perspectives}

Tyramine receptor 1 appears central in controlling physiological processes and defining specific behavioral traits in insects. In recent years, the number of molecular and physiological data have helped shed some light on the role of this receptor. However, despite its importance in controlling the different physiological mechanisms of insects, many questions about the interconnection between the tyraminergic and octopaminergic systems in the modulation of physiology and behavior remain. An intriguing hypothesis suggests that also the ratio between TA and OA receptors might influence behavioral decisions and physiological states. This aspect is evident in social insects, including honeybees, in which both the levels of TA and OA and the expression patterns of the TA and OA receptors seem to influence the caste identities, characterized by well-defined physiological and behavioral profiles $[65,66,96]$. Moreover, the capacity of insects to adapt to particular environmental events or to food deprivation could also be influenced by this complex tyraminergic system and deserves to be further investigated. Finally, little is known on the interactions between the tyraminergic and other hormonal systems, such as the dopaminergic and insulin, and on the corresponding elicited responses in insects. For this reason, exploring biogenic amine receptors appears essential to understand the complex nervous flexibility typical of many insects. Much remains to be understood on the role of TAR1 in insects and its value as a potential target for biopesticides.

Author Contributions: Conceptualization, L.F.; writing-original draft preparation, L.F.; writingreview and editing, L.F., T.R., G.C. and G.B. All authors have read and agreed to the published version of the manuscript.

Funding: This research received no external funding.

Institutional Review Board Statement: Not applicable.

Acknowledgments: We would like to thank Federica Albanese (University of Ferrara, Italy) and Angela Lange (University of Toronto, Canada) for proofreading the manuscript and outstanding support.

Conflicts of Interest: The authors declare no conflict of interest.

\section{References}

1. Neckameyer, W.S.; Leal, S.M. Diverse Functions of Insect Biogenic Amines as Neurotransmitters, Neuromodulators and Neurohormones. Horm. Brain Behav. 2017, 2, 367-401. [CrossRef]

2. Bauknecht, P.; Jèkely, G. Ancient Coexistence of Norepinephrine, Tyramine and Octopamine Signaling in Bilaterians. BMC Biol. 2017, 15, 6. [CrossRef]

3. Roeder, T.; Seifert, M.; Kähler, C.; Gewecke, M. Tyramine and Octopamine: Antagonistic Modulators of Behavior and Metabolism. Arch. Insect Biochem. Physiol. 2003, 54, 1-13. [CrossRef]

4. Pauls, D.; Blechschmidt, C.; Frantzmann, F.; Jundi, B.; Selcho, M. A Comprehensive Anatomical Map of the Peripheral Octopaminergic/Tyraminergic System of Drosophila melanogaster. Sci. Rep. 2018, 8, 15314. [CrossRef]

5. Roeder, T. Tyramine and Octopamine: Ruling Behaviour and Metabolism. Annu. Rev. Entomol. 2005, 50, 447-477. [CrossRef]

6. Downer, R.G.H.; Hiripi, L.; Juhohs, S. Characterization of the Tyraminergic System in the Central Nervous System of the Locust, Locusta migratoria Migratoides. Neurochem. Res. 1993, 18, 1245-1248. [CrossRef]

7. Lange, A.B. Tyramine: From Octopamine Precursor to Neuroactive Chemical in Insects. Gen. Comp. Endocrinol. 2009, 162, 18-26. [CrossRef]

8. Zhukovskaya, M.I.; Polyanovsky, A.D. Biogenic Amines in Insect Antennae. Front. Syst. Neurosci. 2017, 11, 45. [CrossRef] [PubMed] 
9. Hardie, S.L.; Zhang, J.X.; Hirsh, J. Trace Amines Differentially Regulate Adult Locomotor Activity, Cocaine Sensitivity, and Female Fertility in Drosophila melanogaster. Dev. Neurobiol. 2007, 67, 1396-1405. [CrossRef] [PubMed]

10. Wong, R.; Lange, A.B. Octopamine Modulates a Central Pattern Generator Associated with Egg-Laying in the Locust, Locusta migratoria. J. Insect Physiol. 2010, 63, 1-8. [CrossRef] [PubMed]

11. Roeder, T. The Control of Metabolic Traits by Octopamine and Tyramine in Invertebrates. J. Exp. Biol. 2020, 223. [CrossRef] [PubMed]

12. Audsley, N.; Dom, R.E. G Protein Coupled Receptors as Target for Next Generation Pesticides. Insect Biochem. Mol. Biol. 2015, 67, 27-37. [CrossRef]

13. Wu, S.F.; Xu, G.; Qi, Y.X.; Xia, R.Y.; Huang, J.; Ye, G.Y. Two Splicing Variants of a Novel Family of Octopamine Receptors with Different Signaling Properties. J. Neurochem. 2014, 129, 37-47. [CrossRef] [PubMed]

14. Qi, Y.X.; Xu, G.; Gu, G.X.; Mao, F.; Ye, G.Y.; Liu, W.; Huang, J. A New Drosophila Octopamine Receptor Responds to Serotonin Insect Biochem. Mol. Biol. 2017, 90, 61-70. [CrossRef] [PubMed]

15. Bayliss, A.; Roselli, G.; Evans, P.D. A Comparison of the Signaling Properties of Two Tyramine Receptors from Drosophila. J. Neurochem. 2013, 125, 37-48. [CrossRef] [PubMed]

16. Han, K.; Millar, N.; Davis, R.L. A Novel Octopamine Receptor with Preferential Expression in Drosophila Mushroom Bodies. J. Neurosci. 1998, 18, 3650-3658. [CrossRef] [PubMed]

17. Balfanz, S.; Strunker, T.; Frings, S.; Baummann, A. A Family of Octopamine Receptors that Specifically Induce Cyclic AMP Production or $\mathrm{Ca}^{2+}$ Release in Drosophila melanogaster. J. Neurochem. 2005, 93, 440-451. [CrossRef] [PubMed]

18. Grohmann, L.; Blenau, W.; Ebert, P.; Strunker, T.; Baumann, A. Molecular and Functional Characterization of an Octopamine Receptor from Honeybee (Apis mellifera) Brain. J. Neurochem. 2003, 86, 725-735. [CrossRef]

19. Bischof, L.; Enan, E. Cloning, Expression, and Functional Analysis of an Octopamine Receptor from Periplaneta Americana. Insect Biochem. Mol. Biol. 2004, 34, 511-521. [CrossRef]

20. Ohtani, A.; Arai, Y.; Ozoe, F.; Ohta, H.; Narusuye, K.; Huang, J.; Enomoto, K.; Kataoka, H.; Hirota, A.; Ozoe, Y. Molecular Cloning and Heterologous Expression of an Alpha-Adrenergic-like Octopamine Receptor from the Silkworm Bombyx mori. Insect Mol. Biol. 2006, 15, 763-772. [CrossRef]

21. Kim, Y.C.; Lee, H.G.; Lim, J.; Han, K.A. Appetitive Learning Requires the Alpha1-Like Octopamine Receptor OAMB in the Drosophila Mushroom Body Neurons. J. Neurosci. 2013, 33, 1672-1677. [CrossRef]

22. Lee, H.-G.; Seong, C.-S.; Kim, Y.-C.; Davis, R.L.; Han, K.-A. Octopamine Receptor OAMB is Required for Ovulation in Drosophila melanogaster. Dev. Biol. 2003, 264, 179-190. [CrossRef]

23. Crocker, A.; Shahidullah, M.; Levitan, I.B.; Sehgal, A. Identification of a Neural Circuit that Underlies the Effects of Octopamine on sleep: Wake behavior. Neuron 2010, 65, 670-681. [CrossRef]

24. Li, Y.; Fink, C.; El-Kholy, S.; Roeder, T. The octopamine receptor octß2R is essential for ovulation and fertilization in the fruit Fly Drosophila melanogaster. Arch. Insect Biochem. Physiol. 2015, 88, 168-178. [CrossRef] [PubMed]

25. Sujkowski, A.; Wessells, R. Using Drosophila to Understand Biochemical and Behavioral Responses to Exercise. Exerc. Sport Sci. Rev. 2018, 46, 112-120. [CrossRef]

26. Zhang, T.; Branch, A.; Shen, P. Octopamine-Mediated Circuit Mechanism Underlying Controlled Appetite for Palatable Food in Drosophila. Proc. Natl. Acad. Sci. USA 2013, 110, 15431-15436. [CrossRef]

27. Huang, J.; Ohta, H.; Inoue, N.; Takao, H.; Kita, T.; Ozoe, F.; Ozoe, Y. Molecular Cloning and Pharmacological Characterization of a Bombyx Mori Tyramine Receptor Selectively Coupled to Intracellular Calcium Mobilization. Insect Biochem. Mol. Biol. 2009, 39, 842-849. [CrossRef]

28. Cazzamali, G.; Klaerke, D.A.; Grinnelikhuijzen, C.J.P. A New Family of Insect Tyramine Receptor. Biochem. Biophys. Res. Commun. 2005, 338, 1189-1196. [CrossRef] [PubMed]

29. Cabrero, P.; Richmond, L.; Nitabach, M.; Davies, S.A.; Dow, J.A. A Biogenic Amine and a Neuropeptide Act Identically: Tyramine Signals Through Calcium in Drosophila Tubule Stellate Cells. Proc. R. Soc. B 2013, 280, 20122943. [CrossRef]

30. Zhang, H.; Blumenthal, E.M. Identification of Multiple Functional Receptors for Tyramine on an Insect Secretory Epithelium. Sci. Rep. 2017, 7, 168. [CrossRef] [PubMed]

31. Huang, J.; Liu, W.; Qi, Y.X.; Luo, J.; Montell, C. Neuromodulation of Courtship Drive Through Tyramine-Responsive Neurons in the Drosophila brain. Curr. Biol. 2016, 26, 2246-2256. [CrossRef]

32. El-Kholy, S.; Stephano, F.; Li, Y.; Bhandari, A.; Fink, C.; Roeder, T. Expression Analysis of Octopamine and Tyramine Receptors in Drosophila. Cell Tissue Res. 2015, 361, 669-684. [CrossRef]

33. Jonsson, N.N.; Klafke, G.; Corley, S.W.; Tidwell, J.; Berry, C.M.; Koh-Tan, H.C. Molecular Biology of Amitraz Resistance in Cattle Ticks of the Genus Rhipicephalus. Front. Biosci. 2018, 1, 796-810. [CrossRef] [PubMed]

34. Ohta, H.; Ozoe, Y. Molecular Signalling, Pharmacology, and Physiology of Octopamine and Tyramine Receptor as Potential Insect Pest Control Targets. Adv. Insect Physiol. 2014, 46, 73-166. [CrossRef]

35. Saudou, F.; Amlaiky, N.; Plassat, J.L.; Borrelli, E.; Hen, R. Cloning and Characterization of a Drosophila Tyramine Receptor. EMBO J. 1990, 9, 3611-3617. [CrossRef] [PubMed]

36. Finetti, L.; Ferrari, F.; Calò, G.; Cassanelli, S.; De Bastiani, M.; Civolani, S.; Bernacchia, G. Modulation of Drosophila suzukii Type 1 Tyramine Receptor (DsTAR1) by Monoterpenes: A Potential New Target for Next Generation Biopesticides. Pestic. Biochem. Phys. 2020, 165, 104549. [CrossRef] [PubMed] 
37. Ishida, Y.; Ozaki, M. A Putative Octopamine/Tyramine Receptor Mediating Appetite in a Hungry Fly. Naturwissenschaften 2011, 98, 635-638. [CrossRef]

38. Broeck, J.V.; Vulsteke, V.; Huybrechts, R.; De Loof, A. Characterization of a Cloned Locust Tyramine Receptor cDNA by Functional Expression in Permanently Transformed Drosophila S2 Cells. J. Neurochem. 1995, 64, 2387-2395. [CrossRef] [PubMed]

39. Blenau, W.; Balfanz, S.; Baumann, A. Amtyr1: Characterization of a Gene from Honeybee (Apis Mellifera) Brain Encoding a Functional Tyramine Receptor. J. Neurochem. 2000, 74, 900-908. [CrossRef]

40. Ohta, H.; Utsumi, T.; Ozoe, Y. B96Bom Encodes a Bombyx mori Tyramine Receptor Negatively Coupled to Adenylate Cyclase. Insect Mol. Biol. 2004, 12, 217-223. [CrossRef]

41. Von Nickisch-Rosenegk, E.; Krieger, J.S.; Kubick, R.; Laage, J.; Strobel, J.; Strotmann, H. Cloning of Biogenic Amine Receptors from Moths (Bombyx mori and Heliothis virescens). Insect Biochem. Mol. Biol. 1996, 26, 817-827. [CrossRef]

42. Rotte, C.; Krach, C.; Balfanz, S.; Baumann, A.; Walz, B.; Blenau, W. Molecular Characterization and Localization of the First Tyramine Receptor of the American Cockroach (Periplaneta americana). Neuroscience 2009, 162, 1120-1133. [CrossRef]

43. Blenau, W.; Balfanz, S.; Baumann, A. PeaTAR1B: Characterization of a Second Type 1 Tyramine Receptor of the American Cockroach, Periplaneta americana. Int. J. Mol. Sci. 2017, 18, 2279. [CrossRef]

44. Wu, S.F.; Huang, J.; Gong-Yin, Y. Molecular Cloning and Pharmacological Characterization of a Tyramine Receptor from the Rice Stem Borer, Chilo suppressalis (Walker). Pest. Manag. Sci. 2013, 69, 126-134. [CrossRef] [PubMed]

45. Hana, S.; Lange, A.B. Cloning and Functional Characterization of Oct $\beta 2$-Receptor and Tyr1-Receptor in the Chagas Disease Vector, Rhodnius prolixus. Front. Physiol. 2017, 8, 744. [CrossRef] [PubMed]

46. Ma, H.; Huang, Q.; Lai, X.; Liu, J.; Zhu, H.; Zhou, Y.; Deng, X.; Zhou, X. Pharmacological Properties of the Type 1 Tyramine Receptor in the Diamondback Moth, Plutella xylostella. Int. J. Mol. Sci. 2019, 20, 2953. [CrossRef] [PubMed]

47. Finetti, L.; Pezzi, M.; Civolani, S.; Calò, G.; Scapoli, C.; Bernacchia, G. Halyomorpha halys TAR1 Characterization Revealed its Involvement in (E)-2-Decenal Pheromone Perception. J. Exp. Biol. 2020. submitted.

48. Brigaud, L.; GrosmaÎtre, X.; François, M.C.; Jacqion-Joly, E. Cloning and Expression Pattern of a Putative Octopamine/Tyramine Receptor in Antennae of the Noctuid Moth Mamestra brassicae. Cell Tissue Res. 2009, 335, 445-463. [CrossRef]

49. Ono, H.; Yoshikawa, H. Identification of Amine Receptors from a Swallowtail Butterfly Papilio xuthus L.: Cloning and mRNA Localization in Foreleg Chemosensory Organ for Recognition of Host Plants. Insect Biochem. Mol. Biol. 2004, 34, 1247-1256. [CrossRef]

50. Duportets, L.; Barrozo, R.; Bozzolan, F.; Gaertner, C.; Anton, S.; Gadenne, C.; Debernard, S. Cloning of an Octopamine/Tyramine Receptor and Plasticity of its Expression as a Function of Adult Sexual Maturation in the Male Moth Agrotis ipsilon. Insect Mol. Biol. 2010, 19, 489-499. [CrossRef]

51. Braza, M.K.E.; Gazmen, J.D.N.; Yu, E.T.; Nellas, R.B. Ligand-Induced Conformational Dynamics of a Tyramine Receptor from Sitophilus oryzae. Sci. Rep. 2019, 9, 16275. [CrossRef]

52. Baxter, G.D.; Barker, S.C. Isolation of a cDNA for an Octopamine-like, G-Protein Coupled Receptor from the Cattle Tick, Boophilus microplus. Insect Biochem. Mol. Biol. 1999, 29, 461-467. [CrossRef]

53. Rutz, C.; Klein, W.; Schülein, R. N-Terminal Signal Peptides of G Protein-Coupled Receptors: Significance for Receptor Biosynthesis, Trafficking, and Signal Transduction. Prog. Mol. Biol. Transl. Sci. 2015, 132, 267-287. [CrossRef] [PubMed]

54. Moukhametzianov, R.; Warne, T.; Edwards, P.C.; Serrano-Vega, M.J.; Leslie, A.G.; Tate, C.G.; Schertler, G.F. Two Distinct Conformations of Helix 6 Observed in Antagonist-Bound Structures of a beta1-Adrenergic Receptor. Proc. Natl. Acad. Sci. USA 2011, 108, 8228-8232. [CrossRef]

55. Patwardhan, A.; Cheng, N.; Trejo, J. Post-Translational Modifications of G Protein-Coupled Receptors Control Cellular Signaling Dynamics in Space and Time. Pharmacol. Rev. 2021, 73, 120-151. [CrossRef]

56. Yang, Z.; Yang, F.; Zhang, D.; Liu, Z.; Lin, A.; Liu, C.; Xiao, P.; Yu, X.; Sun, J.P. Phosphorylation of G Protein-Coupled Receptors: From the Barcode Hypothesis to the Flute Model. Mol. Pharmacol. 2017, 2, 201-210. [CrossRef] [PubMed]

57. Chini, B.; Parenti, M. G-Protein-Coupled Receptors, Cholesterol and Palmitoylation: Facts about Fats. J. Mol. Endocrinol. 2009, 42, 371-379. [CrossRef] [PubMed]

58. Alexander, S.P.H.; Christopoulos, A.; Davenport, A.P.K.; Eamonn, M.; Alistar, P.J.A.; Veale, E.L.; Armstrong, J.F.; Faccenda, E.; Harding, S.D.; Pawson, A.J.; et al. CGTP Collaborators. The Concise Guide to Pharmacology 2019/20: G Protein-Coupled Receptors. Br. J. Pharm. 2019, 176, S21-S141. [CrossRef]

59. Vogel, R.; Mahalingam, M.; Lüdeke, S.; Huber, T.; Siebert, F.; Sakmar, T.P. Functional Role of the "Ionic Lock"-an Interhelical Hydrogen-Bond Network in Family a Heptahelical Receptors. J. Mol. Biol. 2008, 380, 648-655. [CrossRef] [PubMed]

60. Ohta, H.; Utsumi, T.; Ozoe, Y. Amino Acid Residues Involved in Interaction with Tyramine in the Bombyx Mori Tyramine Receptor. Insect Mol. Biol. 2004, 13, 531-538. [CrossRef]

61. Arakawa, S.; Gocayne, J.D.; McCombie, W.R.; Urquhart, D.A.; Hall, L.M.; Fraser, C.M.; Venter, J.C. Cloning, Localization, and Permanent Expression of a Drosophila Octopamine Receptor. Neuron 1990, 2, 343-354. [CrossRef]

62. Robb, S.; Cheek, T.R.; Hannan, F.L.; Hall, L.M.; Midgley, J.M.; Evans, P.D. Agonist-Specific Coupling of a Cloned Drosophila Octopamine/Tyramine Receptor to Multiple Second Messenger Systems. EMBO J. 1994, 13, 1325-1330. [CrossRef] [PubMed]

63. Enan, E.E. Molecular Response of Drosophila melanogaster Tyramine Receptor Cascade to Plant Essential Oils. Insect Biochem. Mol. Biol. 2005, 35, 309-321. [CrossRef] [PubMed] 
64. Poels, J.; Suner, M.M.; Needham, M.; Torfs, H.; De Rijck, J.; De Loof, A.; Dunbar, S.J.; Vanden Broeck, J. Functional Expression of a Locust Tyramine Receptor in Murine Erythroleukaemia Cells. Insect Mol. Biol. 2001, 10, 541-548. [CrossRef]

65. Mustard, J.A.; Kurshan, P.T.; Hamilton, I.S.; Blenau, W.; Mercer, A.R. Developmental Expression of a Tyramine Receptor Gene in the Brain of the Honeybee, Apis Mellifera. J. Comp. Neurol. 2005, 483, 66-75. [CrossRef]

66. Finetti, L.; Tiedeman, L.; Zhang, X.; Civolani, S.; Bernacchia, G.; Roeder, T. Monoterpenes Alter TAR1-Driven Physiology in Drosophila Species. J. Exp. Biol. 2021, 224, jeb232116. [CrossRef]

67. Kutsukake, M.; Komatsu, A.; Yamamoto, D.; Ishiwa-Chigusa, S. A Tyramine Receptor Gene Mutation Causes a Defective Olfactory Behaviour in Drosophila melanogaster. Gene 2000, 245, 31-42. [CrossRef]

68. Sinakevitch, I.T.; Daskalova, S.M.; Smith, H. The Biogenic Amine Tyramine and its Receptor (AmTyr1) in Olfactory Neuropils in the Honeybee (Apis mellifera) Brain. Front. Syst. Neurosci. 2017, 11, 77. [CrossRef]

69. Thamm, M.; Scholl, C.; Reim, T.; Grübel, K.; Moller, K.; Rossler, W.; Scheiner, R. Neuronal Distribution of Tyramine and the Tyramine Receptor AmTAR1 in the Honeybee Brain. J. Comp. Neurol. 2017, 525, 2615-2631. [CrossRef]

70. McQuillan, H.J.; Barron, A.B.; Mercer, A.R. Age- and Behaviour-Related Changes in the Expression of Biogenic Amine Receptor Genes in the Antennae of Honeybees (Apis mellifera). J. Comp. Physiol. A 2012, 198, 753-761. [CrossRef]

71. Peng, T.; Derstroff, D.; Maus, L.; Bauer, T.; Grüter, C. Forager Age and Foraging State, but not Cumulative Foraging Activity, Affect Biogenic Amine Receptor Gene Expression in the Honeybee Mushroom Bodies. Genes Brain Behav. 2020, 12722. [CrossRef]

72. Ma, Z.; Guo, X.; Lei, H.; Li, T.; Hao, S.; Kang, L. Octopamine and Tyramine Respectively Regulate Attractive and Repulsive Behavior in Locust Phase Changes. Sci.Rep. 2015, 5, 8036. [CrossRef]

73. Ma, Z.; Guo, X.; Liu, J. Translocator Protein Mediates Olfactory Repulsion. FASEB J. 2020, 34, 513-524. [CrossRef]

74. Fussnecker, B.L.; Smith, B.H.; Mustard, J.A. Octopamine and Tyramine Influence the Behavioral Profile of Locomotor Activity in the Honeybee (Apis mellifera). J. Insect Physiol. 2006, 52, 1083-1092. [CrossRef]

75. Saraswati, S.; Fox, L.E.; Soll, D.R.; Wu, C.-F. Tyramine and Octopamine Have Opposite Effects on the Locomotion of Drosophila larvae. J. Neurobiol. 2004, 58, 425-441. [CrossRef]

76. Schützler, N.; Girwert, C.; Hügli, I.; Mohana, G.; Roignant, J.-Y.; Ryglewsky, S.; Duch, C. Tyramine Action on Motoneuron Excitability and Adaptable Tyramine/Octopamine Ratios Adjust Drosophila Locomotion to Nutritional State. Proc. Natl. Acad. Sci. USA 2019, 116, 3805-3810. [CrossRef]

77. Li, Y.; Tiedemann, L.; Von Frieling, J.; Nolte, S.; El-Kholy, S.; Stephano, F.; Gelhaus, C.; Bruchhaus, I.; Fink, C.; Roeder, T. The Role of Monoaminergic Neurotransmission for Metabolic Control in the Fruit Fly Drosophila melanogaster. Front. Syst. Neurosci. 2017, 11, 60. [CrossRef] [PubMed]

78. Fields, P.E.; Woodring, J.P. Octopamine Mobilization of Lipids and Carbohydrates in the House Cricket, Acheta Domesticus. J. Insect Physiol. 1991, 37, 193-199. [CrossRef]

79. Orchard, I.; Carlisle, J.A.; Loughton, B.G.; Gole, J.W.D.; Downer, R.G.H. In Vitro Studies on the Effects of Octopamine on Locust Fat Body. Gen. Comp. Endocrinol. 1993, 48,7-13. [CrossRef]

80. Damrau, C.; Toshima, N.; Tanimura, T.; Brembs, B.; Colomb, J. Octopamine and Tyramine Contribute Separately to the CounterRegulatory Response to Sugar Deficit in Drosophila. Front. Syst. Neurosci. 2018, 11, 100. [CrossRef] [PubMed]

81. Scheiner, R.; Reim, T.; Søvik, E.; Entler, B.V.; Barron, A.B.; Thamm, M. Learning, Gustatory Responsiveness and Tyramine Differences Across Nurse and Forager Honeybees. J. Exp. Biol. 2017, 220, 1443-1450. [CrossRef]

82. LeDue, E.E.; Mann, K.; Koch, E.; Chu, B.; Dakin, R.; Gordon, M.D. Starvation-Induced Depotentiation of Bitter Taste in Drosophila. Curr. Biol. 2016, 26, 2854-2861. [CrossRef]

83. Scheiner, R.; Entler, B.V.; Barron, A.B.; Scholl, C.; Thamm, M. The Effects of Fat Body Tyramine Level on Gustatory Responsiveness of Honeybees (Apis mellifera) Differ Between Behavioral Castes. Front. Syst. Neurosci. 2017, 11, 55. [CrossRef] [PubMed]

84. Guo, X.; Wang, Y.; Sinakevitch, I.; Lei, H.; Smith, B.H. Comparison of RNAi Knockdown Effect of Tyramine Receptor 1 Indiced by dsRNA and siRNA in Brains of the Honeybee, Apis mellifera. J. Insect Physiol. 2018, 111, 47-52. [CrossRef] [PubMed]

85. Wang, Y.; Amdam, G.V.; Daniels, B.C.; Page, R.E., Jr. Tyramine and its Receptor TYR1 Linked Behavior QTL to Reproductive Physiology in Honeybee Workers (Apis mellifera). J. Insect Physiol. 2020, 126, 104093. [CrossRef]

86. Jonsson, N.N.; Hope, M. Progress in the Epidemiology and Diagnosis of Amitraz Resistance in the Cattle Tick Boophilus microplus. Vet. Parasitol. 2007, 146, 193-198. [CrossRef] [PubMed]

87. Kumar, R. Molecular Markers and Their Application in the Monitoring of Acaricide Resistance in Rhipicephalus microplus. Exp. Appl. Acarol. 2019, 78, 149-172. [CrossRef] [PubMed]

88. Cheng, A.C.; He, H.; Davey, R.B. Mutation in a Putative Octopamine Receptor Gene in Amitraz-Resistant Cattle Ticks. Vet. Parasitol. 2007, 148, 379-383. [CrossRef]

89. Baron, S.; Van Der Merwe, N.A.; Madder, M.; Maritz-Olivire, C. SNP Analysis Infers that Recombination is Involved in the Evolution of Amitraz Resistance in Rhipicephalus microplus. PLoS ONE 2015, 10, e0131341. [CrossRef] [PubMed]

90. Farooqui, T. Review of Octopamine in Insect Nervous System. Insect Physiol. 2012, 1. [CrossRef]

91. Gross, A.D.; Temeyer, K.B.; Day, T.A.; Pérez de León, A.A.; Kimber, M.J.; Coats, J.R. Pharmacological Characterization of a Tyramine Receptor from the Southern Cattle Tick, Rhipicephalus (Boophilus) Microplus. Insect Biochem. Mol. Biol. 2015, 63, 47-53. [CrossRef] [PubMed]

92. Jankowska, M.; Rogalska, J.; Wyszkowska, J.; Stankiewicz, M. Molecular Targets for Components of Essential Oils in the Insect Nervous System-A Review. Molecules 2018, 23, 34. [CrossRef] 
93. Isman, M.B. Botanical Insecticides in the Twenty-First Century-Fulfilling Their Promise? Annu. Rev. Entomol. 2020, 65, 233-249. [CrossRef]

94. Gross, A.D.; Temeyer, K.B.; Day, T.A.; Pérez de León, A.A.; Kimber, M.J.; Coats, J.R. Interaction of Plant Essential Oil Terpenoids with the Southern Cattle Tick Tyramine Receptor: A Potential Biopesticide Target. Chem. Biol. Interact. 2017, 263, 1-6. [CrossRef] [PubMed]

95. Ocampo, A.B.; Braza, M.K.E.; Nellas, R.B. The Interaction and Mechanism of Monoterpenes with Tyramine Receptor (SoTyr) of Rice Weevil (Sitophilus oryzae). SN Appl. Sci. 2020, 2, 1592. [CrossRef]

96. Kamhi, J.F.; Arganda, S.; Moreau, C.S.; Traniello, J.F.A. Origins of Aminergic Regulation of Behavior in Complex Insect Social Systems. Front. Syst. Neurosci. 2017, 11, 74. [CrossRef] 